\title{
HUBUNGAN PEMBERIAN ALAT PERMAINAN EDUKATIF DENGAN PERKEMBANGAN MOTORIK HALUS
}

\author{
Tuning Sugianti \\ Akademi Kebidanan Wiyata Mitra Husada Nganjuk \\ Email: tuningsugianti@yahoo.co.id
}

\begin{abstract}
ABSTRAK
Pemberian alat permainan edukatif tidak hanya berfungsi dalam memberikan stimulasi bagi anak. Tetapi juga sangat mempunyai arti dalam perkembangan anak, karena anak memiliki kemampuan penerimaan yang besar terhadap rangsangan dari luar diri anak. Tujuan penelitian ini adalah untuk mengetahui hubungan pemberian alat permainan edukatif dengan perkembangan motorik halus pada anak balita usia 1-5 tahun di Desa Babadan Kecamatan Patianrowo Kabupaten Nganjuk Tahun 2017.

Jenis penelitian adalah penelitian analitik korelasional. Populasi adalah semua anak balita usia 1-5 tahun di Desa Babadan Kecamatan Patianrowo Kabupaten Nganjuk menggunakan teknik sampling simple random sampling sehingga diperoleh sampel sebanyak 68 responden. Penelitian ini dilaksanakan pada bulan Februari 2017. Data dikumpulkan dengan menggunakan angket dan lembar observasi. Variabel independen adalah pemberian alat permainan edukatif, sedangkan variabel dependennya adalah perkembangan motorik halus anak balita usia 1-5 tahun. Analisa data menggunakan uji statistik Spearmen Rank (Rho) dengan $\alpha=0,05$.

Hasil penelitian menunjukkan bahwa 49 responden (72\%) adanya pemberian alat permainan edukatif dan yang tidak diberikan alat permainan edukatif yaitu sebanyak 19 responden (28\%). Sedangkan perkembangan motorik halus pada anak balita usia 1-5 tahun sebanyak 34 responden $(50 \%)$ dalam kategori sesuai, pada kategori meragukan sebanyak 18 responden $(26 \%)$ dan pada kategori penyimpangan sebanyak 16 responden (24\%). Hasil uji korelasi Spearmen Rank (Rho) dengan nilai $r=0,414$. Berdasarkan tingkatan interpretasi nilai koefisien korelasi menunjukkan bahwa ada hubungan antara pemberian alat permainan edukatif dengan perkembangan motorik halus pada anak balita usia 1-5 tahun di Desa Babadan Kecamatan Patianrowo Kabupaten Nganjuk Tahun 2017 pada tingkatan sedang.

Dengan demikian diharapkan seorang ibu untuk dapat memberikan alat permainan edukatif dan ibu lebih memantau perkembangan motorik halus anak supaya perkembangan anak balita dapat sesuai dengan usianya.
\end{abstract}

Kata Kunci : Pemberian alat permainan edukatif, perkembangan motorik halus, anak balita usia 1-5 tahun

\section{PENDAHULUAN}

Perkembangan

merupakan

bertambahnya kemampuan (skill) dalam struktur dan fungsi yang lebih kompleks dalam pola yang teratur sebagai hasil dari proses pematangan yang menyangkut adanya proses diferensiasi dari sel-sel tubuh, jaringan tubuh, organ-organ dan sistem organ yang berkembang sedemikian rupa, sehingga masing-masing dapat memenuhi fungsinya, termasuk juga perkembangan motorik halus sebagai hasil interaksi dengan lingkungan. Keterampilan motorik halus merupakan aktivitas-aktivitas yang menggunakan otot-otot halus pada jari 
tangan seperti menggambar, menggunting, mengikat tali sepatu, mengancingkan kancing baju, dan menarik resleting. Keterampilan motorik halus sangat diperlukan dalam kehidupan sehari-hari (Maryunani, 2013).

Pada masa anak balita usia 1-5 tahun perkembangan motorik halus sangatlah penting karena motorik halus merupakan aspek dasar anak untuk menuju masa sekolah, seperti memegang pensil dengan baik, menulis, mengenal huruf, angka, dan berhitung. Berbagai kemampuan yang dimiliki anak usia dini dalam menggunakan otot-otot fisiknya, baik otot halus dapat menimbulkan rasa percaya diri pada anak bahwa anak mampu menguasai kemampuan motorik serta mampu melakukan segala sesuatu bagi dirinya sendiri untuk mencapai kemandirian (Desmita, 2013).

Alat Permainan Edukatif (APE) yaitu alat permainan yang dapat mengoptimalkan perkembangan anak. Alat ini mengandung nilai pendidikan, dimainkan sesuai dengan usia dan tingkat perkembangan anak. Salah satu APE yang dapat menstimulasi adalah perkembangan aspek kognitif, yaitu dengan pengenalan ukuran, bentuk, dan warna (Soetjiningsih, 2013).

World Health Organitation (WHO) melaporkan bahwa 5-25\% anak di bawah usia 5 tahun menderita disfungsi otak minor, termasuk gangguan perkembangan motorik halus. Sedangkan departemen kesehatan RI melaporkan bahwa 0,4 juta (16\%) anak balita Indonesia mengalami gangguan perkembangan, baik perkembangan motorik halus dan kasar, gangguan pendengaran, kecerdasan kurang dan keterlambatan bicara.

Laporan Eksekutif Kesehatan menurut Kabupaten Nganjuk cakupan pelayanan anak balita serta pemantauan pertumbuhan dan perkembangan pada anak balita tahun 2014 mencapai 3,96 \%.

Berdasarkan studi pendahuluan yang dilakukan pada tanggal 09 Oktober 2016 di Desa Babadan Kecamatan Patianrowo Kabupaten Nganjuk didapatkan data dari 10 anak balita, 6 anak balita diberikan alat permainan edukatif dengan tahap perkembangan motorik halus anak sesuai, 4 anak balita tidak diberikan alat permainan edukatif dengan tahap perkembangan motorik halus anak meragukan. Hal ini menunjukkan bahwa pemberian alat permainan edukatif berpengaruh terhadap perkembangan motorik halus pada anak balita.

Posisi anak balita disatu pihak berada pada masa rawan dan labil manakala anak kurang mendapatkan rangsangan positif dan menyeluruh. Kurangnya stimulasi permainan pada anak dapat menyebabkan penyimpangan tumbuh kembang anak. Bila perkembangan motorik halus ini terlambat, berbahaya bagi penyesuaian sosial dan pribadi anak yang baik sehingga mempengaruhi masa depannya. Serta kurangnya stimulasi atau kegiatan yang bersifat fisik khususnya motorik halus akan mengakibatkan anak memiliki gangguan konsentrasi pada saat anak telah duduk di 
sekolah dasar yang diakibatkan karena motorik halus anak belum matang (Sumantri, 2014).

Pada masa tersebut perkembangan anak balita akan mulai diasah sesuai dengan kebutuhannya. Untuk meningkatkan perkembangan motorik halusnya, setiap anak balita perlu mendapat stimulasi rutin sedini mungkin. Upaya pengembangan anak balita dapat dilakukan dengan berbagai cara, di antaranya adalah dengan metode bermain untuk mengembangkan kemampuan motorik halusnya. Tumbuh kembang optimal dapat tercapai apabila ada interaksi antara anak dan orang tua, terutama stimulasi sangat bermanfaat bagi proses perkembangan anak secara keseluruhan (Soetjiningsih, 2013).

Penelitian ini bertujuan untuk mengetahui hubungan pemberian alat permainan edukatif dengan perkembangan motorik halus pada anak balita usia 1-5 tahun di Desa Babadan Kecamatan Patianrowo Kabupaten Nganjuk Tahun 2017.

\section{METODE PENELITIAN}

Penelitian ini menggunakan penelitian analitik korelasi, yang bertujuan untuk mencari hubungan pemberian alat permainan edukatif dengan perkembangan motorik halus, dengan desain penelitian rancangan cross sectional. Populasi dalam penelitian ini adalah Semua anak balita usia 1-5 tahun di Desa Babadan Kecamatan Patianrowo Kabupaten Nganjuk tahun 2017 sebanyak 202 responden, dengan sampel sejumlah 68 responden dengan menggunakan metode simple random sampling. Setelah data terkumpul melalui angket dan lembar observasi, dan analisis statistik dengan menggunakan uji Spearman Rank (Rho).

\section{HASIL PENELITIAN}

Tabel 1: Distribusi Frekuensi Berdasarkan Pemberian Alat Permainan Edukatif lbu di Desa Babadan, Kecamatan Patianrowo, Kabupaten Nganjuk Tahun 2017

\begin{tabular}{clcc}
\hline No. & Pemberian & Jumlah & Persentase \\
\hline $\mathbf{1}$ & Diberikan & 49 & $\mathbf{7 2} \%$ \\
\hline $\mathbf{2}$ & $\begin{array}{l}\text { Tidak } \\
\text { Diberikan }\end{array}$ & 19 & $\mathbf{2 8} \%$ \\
\multicolumn{2}{l}{ Total } & $\mathbf{6 8}$ & $\mathbf{1 0 0 \%}$ \\
\hline
\end{tabular}

Berdasarkan tabel 1 didapatkan bahwa ibu yang memberikan alat permainan edukatif sebanyak 49 responden (72\%) dan yang tidak memberikan alat permainan edukatif sebanyak 19 responden (28\%).

Tabel 2: Distribusi Frekuensi Berdasarkan Perkembangan Motorik Halus pada Anak Balita Usia 1-5 Tahun di Desa Babadan, Kecamatan Patianrowo, Kabupaten Nganjuk Tahun 2017

\section{No Perkembangan Jumlah Persentase} Motorik Halus

\begin{tabular}{|c|c|c|}
\hline 1. Sesuai & 34 & $50 \%$ \\
\hline Meragukan & 18 & $26 \%$ \\
\hline 3. Penyimpangan & 16 & $24 \%$ \\
\hline Total & 68 & $100 \%$ \\
\hline
\end{tabular}

Sumber: Data Primer Penelitian, 2017

Berdasarkan tabel 2 didapatkan bahwa tahap perkembangan motorik halus anak sesuai tahap perkembangannya sebanyak 34 responden (50\%), tahap perkembangan motorik halus anak meragukan sebanyak 18 responden $(26 \%)$, dan tahap perkembangan 
motorik halus anak yang kemungkinan ada penyimpangan sebanyak 16 responden (24\%).

Berdasarkan hasil penelitian, data yang telah ditabulasi, diolah menggunakan uji statistik Spearman Rank (Rho) dengan nilai $r$ $=0,414$. Berdasarkan tingkatan interpretasi nilai koefisien korelasi menunjukkan bahwa ada hubungan antara pemberian Alat Permainan Edukatif dengan Perkembangan Motorik Halus pada anak balita usia 1-5 tahun di Desa Babadan, Kecamatan Patianrowo, Kabupaten Nganjuk tahun 2017 pada tingkatan sedang.

\section{PEMBAHASAN}

Sebagian besar responden yang memberi alat permainan edukatif, yaitu sebanyak 49 responden (72\%). Sedangkan yang tidak memberi alat permainan edukatif, yaitu sebanyak 19 responden (28\%).

Memberikan alat permainan edukatif sebagai sarana untuk merangsang anak dalam mempelajari sesuatu tanpa anak menyadarinya, baik menggunakan teknologi modern, konvensional maupun tradisional (Yuniarti 2015).

Hampir seluruhnya adanya pemberian Alat Permainan Edukatif pada responden ibu anak balita usia 1-5 tahun di Desa Babadan, Kecamatan Patianrowo, Kabupaten Nganjuk, dikarenakan banyaknya ibu yang berumur 21-35 tahun. Pada usia tersebut termasuk dalam kategori reproduksi sehat. Sehingga ibu lebih mampu dalam berfikir dan pemberian Alat Permainan Edukatif pun bisa diberikan sesuai usia anak balitanya. Tingkat pendidikan responden rata-rata cukup yaitu pendidikan menengah, sehingga ibu sudah memiliki dasar-dasar pola berfikir dewasa dan rasional serta semakin mudah menerima informasi dan mengerti tentang manfaat pemberian Alat Permainan Edukatif. Pekerjaan responden rata-rata adalah ibu rumah tangga, sehingga ibu memiliki banyak waktu dan akses luas dalam memberikan Alat Permainan Edukatif kepada anaknya tanpa harus terganggu dengan status pekerjaan (Notoatmodjo, 2012).

Sebagian besar responden anak balita usia 1-5 tahun yang memiliki perkembangan motorik halus sesuai yaitu sebanyak 34 responden (50\%), sebanyak 18 responden (26\%) memiliki perkembangan motorik meragukan, sebanyak 16 responden (24\%) memiliki perkembangan motorik kemungkinan ada penyimpangan.

Perkembangan motorik halus adalah Kemampuan gerak tubuh yang menggunakan otot-otot kecil, sebagian besar atau seluruh anggota tubuh anak sesuai usia (Yuniarti, 2015).

Hampir seluruh responden mempunyai perkembangan motorik halus sesuai, dikarenakan sebagian besar ibu berusia 21 35 tahun yang termasuk usia reproduksi sehat, karena hal ini dapat menciptakan kondisi lingkungan dan tempat tinggal yang kondusif bagi keluarga kecil dan sejahtera. Serta ibu dapat lebih leluasa dalam memberikan perlindungan kepada anaknya 
dalam proses membentuk perkembangan motorik halus.

Sebagian besar responden yang memberi alat permainan edukatif dan memiliki anak balita perkembangan motorik halus sesuai sebanyak 29 responden (43\%), yang memberi alat permainan edukatif dan memiliki anak balita dengan perkembangan motorik halus meragukan sebanyak 15 responden (22\%), yang memberi alat permainan edukatif dan memiliki anak balita dengan perkembangan motorik halus kemungkinan ada penyimpangan sebanyak 5 responden (7\%). Sedangkan responden yang tidak memberi alat permainan edukatif dan memiliki anak balita perkembangan motorik halus sesuai sebanyak 5 responden $(7 \%)$, yang tidak memberi alat permainan edukatif dan memiliki anak balita dengan perkembangan motorik halus meragukan sebanyak 3 responden (4\%), yang tidak memberi alat permainan edukatif dan memiliki anak balita dengan perkembangan motorik halus kemungkinan ada penyimpangan sebanyak 11 responden (17\%).

Demikian pula hasil pengujian korelasi Spearman Rank (Rho) didapatkan hasil uji korelasi Spearman Rank (Rho) dengan nilai $r$ $=0,414$. Berdasarkan tingkatan interpretasi nilai koefisien korelasi menunjukkan bahwa ada hubungan antara pemberian Alat Permainan Edukatif dengan Perkembangan Motorik Halus pada anak balita usia 1-5 tahun di Desa Babadan, Kecamatan
Patianrowo, Kabupaten Nganjuk tahun 2017 pada tingkatan sedang.

\section{KESIMPULAN}

Berdasarkan hasil analisis dan pembahasan pada bab sebelumnya, maka peneliti dapat menyimpulkan: Dari 68 responden yang dilakukan penelitian, pemberian Alat Permainan Edukatif pada anak balita usia 1-5 tahun di Desa Babadan, Kecamatan Patianrowo, Kabupaten Nganjuk Tahun 2017 secara dominan pada kategori diberikan Alat Permainan Edukatif, yaitu sebanyak 49 responden (72\%), sedangkan yang tidak diberikan Alat Permainan Edukatif yaitu sebanyak 19 responden (28\%).Dari 68 responden yang dilakukan penelitian, perkembangan motorik Halus pada anak balita usia 1-5 tahun di Desa Babadan, Kecamatan Patianrowo, Kabupaten Nganjuk Tahun 2017 secara dominan pada kategori yang sesuai yaitu sebanyak 34 responden (50\%), sedangkan pada kategori meragukan sebanyak 18 responden (26\%) dan pada kategori penyimpangan sebanyak 16 responden (24\%). Hasil uji korelasi Spearman Rank (Rho) dengan nilai $r=0,414$. Berdasarkan tingkatan interpretasi nilai koefisien korelasi menunjukkan bahwa ada hubungan antara pemberian Alat Permainan Edukatif dengan Perkembangan Motorik Halus pada anak balita usia 1-5 tahun di Desa Babadan, Kecamatan Patianrowo, Kabupaten Nganjuk tahun 2017 pada tingkatan sedang. 


\section{SARAN}

Saran bagi penelitian selanjutnya diharapkan dapat mengembangkan variabel penelitian dan menambah jumlah sampel sehingga didapatkan hasil penelitian yang lebih baik.

\section{DAFTAR PUSTAKA}

Desmita, Rosana. 2013. Tumbuh Kembang Anak. Jakarta: Rineka Cipta

Maryunani, Anik. 2013. Ilmu Kesehatan Anak dalam Kebidanan. Jakarta: CV. Trans Info Media

Notoatmodjo, Soekidjo. 2012. Metodologi Penelitian Kesehatan. Jakarta: Rineka Cipta

Soetjiningsih. 2015. Buku Ajar II Tumbuh Kembang Anak Dan Remaja. Jakarta: Iday

Sumantri. 2014. Pengasuhan Dan Pembimbingan Tumbuh Kembang Anak. Jakarta: Salemba Medika

Yuniarti, Sri. 2015. Asuhan Tumbuh Kembang Neonatus, Bayi-Balita Dan Anak Pra-Sekolah. Bandung: Refika Aditama 